\title{
DNA Double-Strand Break Repairs and Their Application in Plant DNA Integration
}

\author{
Hexi Shen ${ }^{1,2, *}$ and Zhao $\mathrm{Li}^{1,2}$ \\ 1 School of Municipal and Environmental Engineering, Shandong Jianzhu University, Jinan 250101, China; \\ lizhao19@sdjzu.edu.cn \\ 2 Resources and Environment Innovation Institute, Shandong Jianzhu University, Jinan 250101, China \\ * Correspondence: shenhexi19@sdjzu.edu.cn
}

check for

updates

Citation: Shen, H.; Li, Z. DNA Double-Strand Break Repairs and

Their Application in Plant DNA Integration. Genes 2022, 13, 322. https://doi.org/10.3390/ genes13020322

Academic Editor: Albert Jeltsch

Received: 19 January 2022

Accepted: 7 February 2022

Published: 9 February 2022

Publisher's Note: MDPI stays neutral with regard to jurisdictional claims in published maps and institutional affiliations.

Copyright: (C) 2022 by the authors. Licensee MDPI, Basel, Switzerland. This article is an open access article distributed under the terms and conditions of the Creative Commons Attribution (CC BY) license (https:// creativecommons.org/licenses/by/ $4.0 /)$.

\begin{abstract}
Double-strand breaks (DSBs) are considered to be one of the most harmful and mutagenic forms of DNA damage. They are highly toxic if unrepaired, and can cause genome rearrangements and even cell death. Cells employ two major pathways to repair DSBs: homologous recombination (HR) and non-homologous end-joining (NHEJ). In plants, most applications of genome modification techniques depend on the development of DSB repair pathways, such as Agrobacterium-mediated transformation (AMT) and gene targeting (GT). In this paper, we review the achieved knowledge and recent advances on the DNA DSB response and its main repair pathways; discuss how these pathways affect Agrobacterium-mediated T-DNA integration and gene targeting in plants; and describe promising strategies for producing DSBs artificially, at definite sites in the genome.
\end{abstract}

Keywords: DSB; DNA repair; HR; NHEJ; T-DNA integration; gene targeting

\section{Introduction}

Double-strand breaks (DSBs) are considered to be one of the most harmful and mutagenic forms of DNA damage. They may arise as an outcome of normal cellular metabolism, but occur more frequently due to external factors such as ultraviolet (UV) radiation, ionizing radiation and genotoxic regents [1]. Being sessile organisms, plants are continually subjected to abiotic stress conditions, especially UV-B light and heavy metal pollutions, as well as to unexpected environmental changes that can also induce DNA damage [2]. DSBs are highly toxic if unrepaired, and can cause genome rearrangements and even cell death. Fortunately, cells possess highly conserved systems to recognize DSB signals and then trigger various downstream events to bring about repair. Two main DSB repair pathways are homologous recombination (HR) and non-homologous end-joining (NHEJ). The HR pathway recovers the genomic sequence precisely by using a template from the sister chromatid, the homologous chromosome or the homologous repeats in close proximity for accurate repair [3,4]. In contrast, the DSB ends are rejoined directly by the NHEJ pathway regardless of the sequence homology, leading to small deletions and insertions at the break site. HR and NHEJ are highly conserved in eukaryote cells, but their significance may be different depending on the cell type or the stage of the cell cycle. Unicellular eukaryotes mostly depend on HR to repair DSBs such as yeast Saccharomyces cerevisiae with small genomes, whereas the NHEJ pathway is the predominant one in higher eukaryotes such as humans and Arabidopsis, with large genomes containing many repeat sequences $[5,6]$. In plants, most applications of genome modification technique depend on the development of DSB repair pathways, such as Agrobacterium-mediated transformation (AMT) and gene targeting (GT). In this review, we summarize first the DNA DSB response and its main repair pathways. We also explore how these pathways affect Agrobacterium-mediated T-DNA integration and gene targeting in plants. In the last section, we discuss the strategies of producing site-specific DSBs artificially in the genome. 


\section{DNA Damage Response}

The DNA damage response (DDR) is a signal transduction pathway that affects many aspects of cellular physiology (cell-cycle arrest, DNA repair, apoptosis and senescence) [7]. Key regulators of this pathway belong to the phosphatidylinositol 3-kinase-like protein kinase (PIKKs) family [8]. They control the downstream amplification of DNA damage signals by recruitment and phosphorylation of their substrates. The current understanding of the DDR mechanism in mammals is mostly dependent on the study of the three most important members of the PIKK family: ATM (Ataxia Telangiectasia Mutated), ATR (ATM and Rad-3 related) and DNA-PKcs (DNA-dependent protein kinase catalytic subunit) [9-12]. In human cells, MRE11-RAD50-NBS1 (MRN) complex and Ku70/80 heterodimer recognize DSBs signals and then trigger the activation of ATM and DNA-PKcs, respectively. Subsequently, the levels of DNA repair proteins are activated and/or induced. In addition, the appearance of areas in the genome with ssDNA as a consequence of DNA damage or repair leads to the recruitment and activation of the other master regulator, ATR. Afterwards ATM and ATR phosphorylate lots of downstream substrates, including CHK1 and CHK2, which generate a downstream amplification by protein activation and repression. These signals are subsequently transmitted to the tumor-suppressor protein p53, resulting in cell-cycle arrest and DNA repair. Another example includes the histone protein H2AX. Local phosphorylation of histone $\mathrm{H} 2 \mathrm{AX}$ at damage sites leads to local accumulation of repair proteins, which is enhanced by ubiquitination and poly (ADP)-ribosylation of specific damage response pathway components. Multiple studies in human cells have concluded that ATM phosphorylates histone H2AX and chromatin remodeling factor KAP1 with DNA-PKcs, due to the functional redundancy between ATM and DNA-PKcs in the process [13-15]. However, a recent report discovered that DNA-PKcs responds to IR-mediated DSBs very quickly, and its enzymatic activity is able to initiate the DDR directly [16].

Plant DDRs are not fully understood in detail, even though the main actors of the DDR signaling pathway have been identified. So far, only a few homologous genes in plants have been characterized that are related to DDR. The Arabidopsis ATM and ATR proteins are the key DNA damage sensors for the response to DNA damage [17,18]. The MRN complex recognizes DSBs in plant cells and then activates ATM activity. Despite the conservation nature of ATM and ATR kinases in plants and animals, they seem to behave distinctively differently under DNA stress. Many genes required for the cell cycle and DNA damage checkpoints in animals have no ortholog in plants, such as CHK1, CHK2 and p53 [19]. Instead, a downstream factor called SOG1 (suppressor of $\gamma$ response 1) functions as a central hub in the Arabidopsis DDR process [20,21]. As a plant-specific transcription factor, SOG1 controls the expression of most of the genes related to $\gamma$ irradiation which ultimately induce cell-cycle arrest, DNA repair or programmed cell death [22,23]. In addition to being a target of SOG1, WEE1 is another critical downstream target of the ATR-ATM signaling cascades, and regulates cell-cycle arrest directly by phosphorylating and inhibiting CDKs, and/or indirectly by phosphorylating FBL17 in response to DNA damage [24,25]. Furthermore, recent findings revealed that the E2FA-RBR1 (retinoblastoma-related 1) complexes are responsible for the activation of the cell cycle checkpoint and likely function in the plant DDR in a SOG1-independent manner [26-28]. The role of E2FA-RBR1 complexes in DDR relies on ATM/ATR and CYCB1/CDKB activity, but the exact molecular mechanisms remain to be determined (Figure 1 ). 


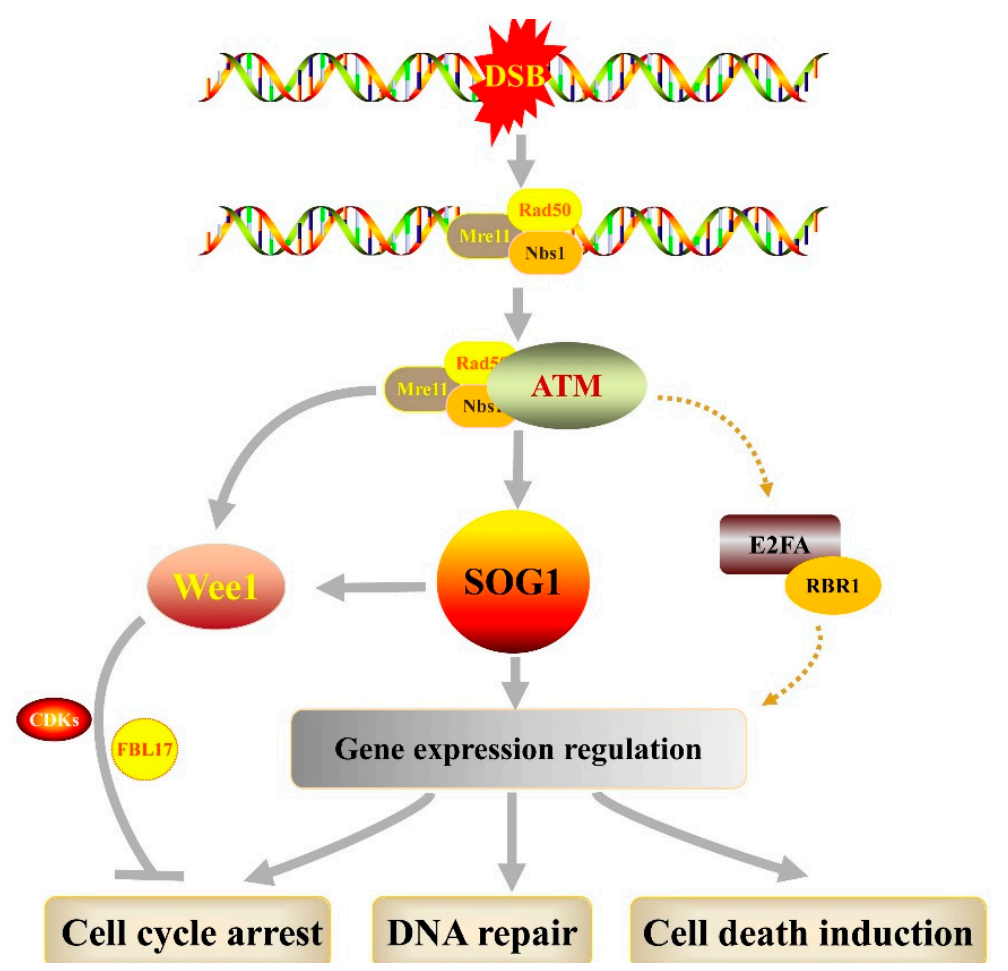

Figure 1. Overview of DNA Double-strand break (DSB) damage response in plants. MRN (MRE11RAD50-NBS1) complex first recognizes the DNA DSB resulting in ATM (Ataxia Telangiectasia Mutated) activation. Subsequently, the ATM amplify signals by phosphorylation of downstream substrates, such as SOG1 (suppressor of $\gamma$ response 1). The SOG1 functions as a central hub and controls the expression of hundreds of genes, which ultimately induce cell-cycle arrest, DNA repair or programmed cell death.

\section{DSB Repair via Homologous Recombination}

Homologous recombination (HR) promotes genome stability by facilitating the errorfree repair of DSBs, interstrand crosslinks (ICLs), and DNA gaps, during and after DNA replication [29]. HR is a key repair pathway in the S and G2 phases of the cell cycle. HR pathway requires homologous sequences that act as a template, and the homologous sister chromatid is the preferred template in somatic cells. The information from the homologous sister chromatid is copied into, and replaces, the damaged region, resulting in precise repair. The homology search and DNA strand invasion are major steps in this process. Both are catalyzed by DNA-dependent ATPase Rad51, which can bind cooperatively to ssDNA to form helical nucleoprotein filaments [30]. HR consists of three stages, and Rad51 functions in all of them: pre-synapsis, synapsis and post-synapsis [31] (Figure 2).

At the beginning of pre-synapsis, the DSB is processed to generate ssDNA overhangs by $5^{\prime}$ to $3^{\prime}$ DNA end resection involving the Exo1 and MRN complex. In yeast, the MRX (MRE11-RAD50-XRS2) complex and Sae2 assist the short resection (50-200 nt), while more extensive resection involves either Exo1 or Sgs1 in combination with Dna2 [32]. After end resection, ssDNA overhangs are coated by RPA to protect against DNA degradation and the formation of secondary structures, which is required for the formation of competent Rad51 filaments [33]. However, RPA binding also prevents Rad51 filament assembly [34]. This inhibitory effect can be conquered by at least three different kinds of mediator proteins: Rad51 paralogs, Rad52, and BRCA2 [29]. In Arabidopsis, most of the major players in HR are identified and characterized $[35,36]$ (Table 1). 


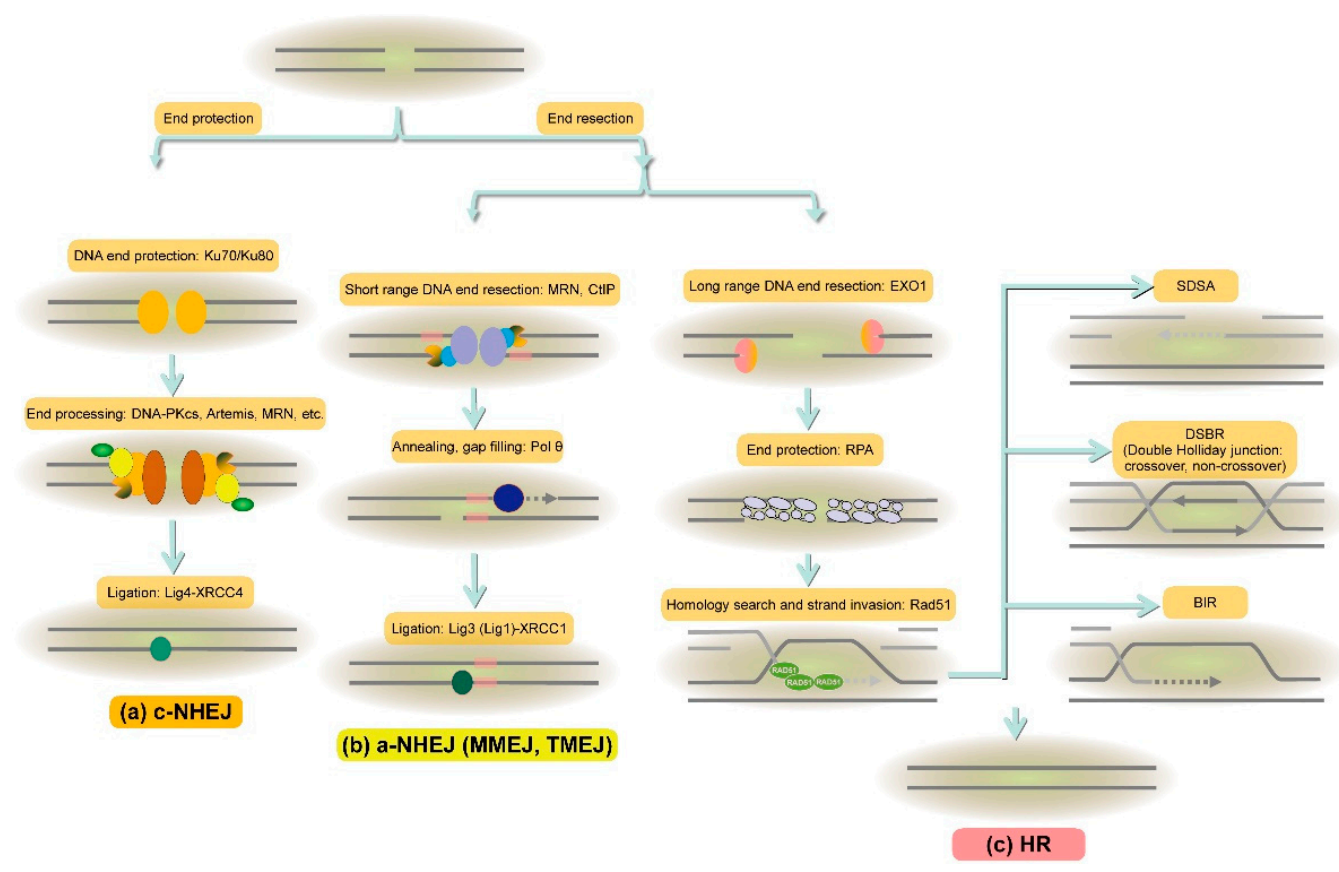

Figure 2. The major pathways of DNA DSB repair: (a) During the c-NHEJ, DSB is recognized and bound by $\mathrm{Ku} 70 / 80$. The binding of $\mathrm{Ku} 70 / 80$ can protect the DSB ends from end resection, followed by the recruitment of other factors to perform end processing. The Ligase4-XRCC4 complex executes the final ligation step; (b) in a-NHEJ (MMEJ or TMEJ) pathways, PARP1 is supposed to serve as a platform at the broken end to recruit other factors, including the DNA polymerase $\theta$ (Pol $\theta$ ) which utilizes short microhomologies (indicated as pink boxes) for efficient and processive DNA synthesis. The microhomology-mediated joints between the two DNA ends are stabilized by Pol $\theta$ and work as primers for gap filling, while the XRCC1-Ligase3 (Ligase1) complex is responsible for the final ligation step; (c) HR is initiated by the long-range DNA end resection involving Exo1 and MRN complex. Subsequently, ssDNA overhangs are coated by RPA for protection against winding of the DNA. The Rad51 filament then facilitates a fast and efficient homology search and DNA strand invasion, resulting in a D-loop structure. One of three sub-pathways of HR complete the repair in the end: synthesis-dependent strand annealing (SDSA), double-strand break repair (DSBR) or break-induced replication (BIR) (does not exist in plants).

The Rad51 filament facilitates a fast and efficient homology search and DNA strand invasion, resulting in a D-loop structure. Rad54 is required for searching for homology, stimulates DNA strand invasion by the Rad51 filament, and also functions after synapsis [37,38]. DNA synthesis is primed by the $3^{\prime}$ invading strand, using the donor strand as a template.

After extension of the $3^{\prime}$ invading strand, repair is finalized by one of at least three different sub-pathways of HR. In the classical double-strand break repair (DSBR) subpathway, Rad52 and Rad59 stimulate the arrest of the second end by the D-loop, whereafter two Holliday junctions ( $\mathrm{dHJ}$ ) are formed [39]. These dHJs are either dissolved into noncrossover products by a RecQ helicase, such as yeast Sgs1, or human BLM helicase, or decomposed into crossover/non-crossover products by a structure-specific endonuclease. In general, non-crossovers are much more predominant in mitotic HR [40]. Crossovers are able to produce genomic rearrangements and large-scale loss of heterozygosity (LOH) [41]. The Mph1 helicase suppresses the DSBR pathway to avoid crossover events in mitotic cells by dissociating D-loop formations, to promote annealing of the extended $3^{\prime}$ end to complementary sequences at the other side of the DSB, resulting in the synthesis-dependent strand annealing (SDSA) sub-pathway [42]. It seems that the Rad51 protein has some inhibitory activity that counters the capture of the second end and $\mathrm{dHJ}$ formation, indicating an inherent mechanistic bias toward SDSA [43]. The D-loop can convert into a replication fork in the absence of a second end, leading to the break-induced replication (BIR) sub- 
pathway. During BIR, the replication fork restores the integrity of a broken chromosome by copying the whole distal arm of the template chromosome, producing LOH [44]. However, no experimental evidence has been shown of the occurrence of BIR in plants [45].

Table 1. HR proteins in human, yeast and Arabidopsis.

\begin{tabular}{|c|c|c|c|c|}
\hline Homo sapiens & $\begin{array}{l}\text { Saccharomyces } \\
\text { cerevisiae }\end{array}$ & $\begin{array}{l}\text { Arabidopsis } \\
\text { thaliana }\end{array}$ & $\begin{array}{c}\text { Arabidopsis } \\
\text { Gene Number }\end{array}$ & Function \\
\hline Rad51 & Rad51 & Rad51 & At5g20850 & $\begin{array}{l}\text { RecA homologue } \\
\text { Strand invasion }\end{array}$ \\
\hline $\begin{array}{c}\text { MRN complex: } \\
\text { Mre11-Rad50-Nbs1 }\end{array}$ & $\begin{array}{c}\text { MRX complex: } \\
\text { Mre11-Rad50-Xrs2 }\end{array}$ & $\begin{array}{c}\text { MRN complex: } \\
\text { Mre11-Rad50-Nbs1 }\end{array}$ & $\begin{array}{l}\text { At5g54260 } \\
\text { At } 2 g 31970 \\
\text { At3g02680 }\end{array}$ & $\begin{array}{c}\text { DNA binding } \\
\text { Nuclease activities } \\
\text { DSB end processing } \\
\text { DNA-damage checkpoints }\end{array}$ \\
\hline CtIP & Sae2 & Com1 & At3g52115 & $\begin{array}{l}\text { DSB end processing } \\
\text { DNA strand transition }\end{array}$ \\
\hline Exo1 & Exo1 & $\begin{array}{l}\text { Exo1A } \\
\text { Exo1B }\end{array}$ & $\begin{array}{l}\text { At1g29630 } \\
\text { At1g18090 }\end{array}$ & DSB end processing \\
\hline BLM & Sgs1 & $\begin{array}{l}\operatorname{RecQ} 4 A \\
\operatorname{RecQ} 4 B\end{array}$ & $\begin{array}{l}\text { At1g10930 } \\
\text { At1g60930 }\end{array}$ & $\begin{array}{l}\text { DSB end processing } \\
\text { RecQ helicases }\end{array}$ \\
\hline $\begin{array}{l}\text { RPA1 } \\
\text { RPA2 } \\
\text { RPA3 }\end{array}$ & $\begin{array}{l}\text { RPA1 } \\
\text { RPA2 } \\
\text { RPA3 }\end{array}$ & $\begin{array}{l}\text { RPA1 } \\
\text { RPA2 } \\
\text { RPA3 }\end{array}$ & $\begin{array}{l}\text { At2g06510 } \\
\text { At4g19130 } \\
\text { At5g45400 } \\
\text { At5g08020 } \\
\text { At5g61000 }\end{array}$ & ssDNA binding \\
\hline $\begin{array}{l}\text { Rad51B-Rad51C } \\
\text { Rad51C-XRCC3 } \\
\text { Rad51D-XRCC2 }\end{array}$ & Rad55-Rad57 & $\begin{array}{l}\text { Rad51B-Rad51C } \\
\text { Rad51C-XRCC3 } \\
\text { Rad51D-XRCC2 }\end{array}$ & $\begin{array}{l}\text { At2g28560 } \\
\text { At2g45280 } \\
\text { At5g57450 } \\
\text { At1g07745 } \\
\text { At5g64520 }\end{array}$ & $\begin{array}{l}\text { ssDNA binding } \\
\text { Recombination mediator }\end{array}$ \\
\hline Rad52 & Rad52 & Rad52 & $\begin{array}{l}\text { At1g71310 } \\
\text { At5g47870 }\end{array}$ & $\begin{array}{l}\text { ssDNA binding and annealing } \\
\text { Recombination mediator } \\
\text { Interacts with Rad51 and RPA }\end{array}$ \\
\hline BRCA1 & -1 & BRCA1 & At $4 g 21070$ & $\begin{array}{l}\text { Checkpoint mediator } \\
\text { Recombination mediator }\end{array}$ \\
\hline BRCA2 & -1 & $\begin{array}{l}\text { BRCA2-1 } \\
\text { BRCA2-2 }\end{array}$ & $\begin{array}{l}\text { At5g01630 } \\
\text { At4g00020 }\end{array}$ & Recombination mediator \\
\hline Rad54 & Rad54 & Rad54 & At3g19210 & $\begin{array}{l}\text { ATP-dependent dsDNA } \\
\text { translocase } \\
\text { Stimulates the D-loop reaction }\end{array}$ \\
\hline FancM & Mph1 & FancM & At1g35530 & $\begin{array}{c}\text { Helicase activity } \\
\text { Dissociates D-loop formation and } \\
\text { facilitates single-strand annealing }\end{array}$ \\
\hline
\end{tabular}

${ }^{1}$ No yeast equivalent has been identified.

\section{DSB Repair via Non-Homologous End-Joining}

Non-homologous end-joining (NHEJ) plays a major role in the repair of plant and mammal DSBs $[5,6]$. The NHEJ process seems to be relatively simple and straightforward: it rejoins broken ends directly, without the requirement of long runs of end-resection and searching for a homologous repair template. NHEJ pathways are subdivided into the canonical NHEJ (c-NHEJ) and a group of less well elucidated alternative NHEJ (a-NHEJ) pathways, which are also called microhomology-mediated end-joining (MMEJ) or polymerase theta-mediated end-joining (TMEJ) [46-48]. Still, many factors are required for NHEJ pathways that demand precise cooperation and timely regulation (Table 2). In general, DSB repair by NHEJ can be precise, but may also cause small nucleotide deletions and insertions at the junction, which changes the nucleotide sequence information surrounding the repair region [49]. As a result, NHEJ is considered as an error-prone DNA repair pathway. Our previous studies in Arabidopsis NHEJ-deficient mutants indicated that a-NHEJ is a more error-prone mechanism compared to c-NHEJ [50]. 
Table 2. NHEJ proteins in human, yeast and Arabidopsis.

\begin{tabular}{|c|c|c|c|c|}
\hline Homo sapiens & $\begin{array}{l}\text { Saccharomyces } \\
\text { cerevisiae }\end{array}$ & $\begin{array}{l}\text { Arabidopsis } \\
\text { thaliana }\end{array}$ & $\begin{array}{l}\text { Arabidopsis } \\
\text { Gene Number }\end{array}$ & Function \\
\hline Ku70/Ku80 & Ku70/Ku80 & $\mathrm{Ku} 70 / \mathrm{Ku} 80$ & $\begin{array}{l}\text { At1g16970 } \\
\text { At1g48050 }\end{array}$ & DSB end binding and protection \\
\hline DNA-PKcs & -1 & -1 & & protein kinase \\
\hline Artemis & Snm1/PSO2 & Snm1 & At3g26680 & DNA end processing \\
\hline $\begin{array}{c}\text { MRN complex: } \\
\text { Mre11-Rad50-Nbs1 }\end{array}$ & $\begin{array}{l}\text { MRX complex: } \\
\text { Mre11-Rad50-Xrs2 }\end{array}$ & $\begin{array}{l}\text { MRN complex: } \\
\text { Mre11-Rad50-Nbs1 }\end{array}$ & $\begin{array}{l}\text { At5g54260 } \\
\text { At2g31970 } \\
\text { At3g02680 }\end{array}$ & $\begin{array}{c}\text { DNA binding } \\
\text { Nuclease activities } \\
\text { DSB ends processing } \\
\text { DNA-damage checkpoints }\end{array}$ \\
\hline PNKP & Tpp1 & ZDP & At3g14890 & DNA end processing \\
\hline Pol $\lambda$ & $-{ }^{1}$ & Pol $\lambda$ & At1g10520 & $\begin{array}{l}\text { DNA polymerase } \\
\text { DNA end processing }\end{array}$ \\
\hline 53BP1 & Rad9 & Rad9 & At3g05480 & DNA end processing \\
\hline DNA ligase IV & Dnl4 & $\operatorname{lig} 4$ & At5g57160 & ATP-dependent DNA ligase \\
\hline XRCC4 & Lif1 & XRCC4 & At3g23100 & complex with lig4 \\
\hline XLF/Cernunnos & Nej1 & -1 & & complex with lig4/XRCC4 \\
\hline Parp1 & $-{ }^{1}$ & Parp1 & At $2 g 31320$ & $\begin{array}{c}\text { DNA end binding } \\
\text { NAD + ADP-ribosyltransferase }\end{array}$ \\
\hline Parp2 & $-{ }^{1}$ & Parp2 & At4g02390 & $\begin{array}{c}\text { DNA end binding } \\
\text { NAD + ADP-ribosyltransferase }\end{array}$ \\
\hline Parp3 & $-{ }^{1}$ & Parp3 & At5g22470 & $\begin{array}{c}\text { DNA end binding } \\
\text { NAD + ADP-ribosyltransferase }\end{array}$ \\
\hline CtIP & Sae2 & Com1 & At3g52115 & DNA end processing \\
\hline DNA ligase III & -1 & -1 & & ATP-dependent DNA ligase \\
\hline XRCC1 & -1 & XRCC1 & At1g80420 & complex with lig3 \\
\hline Pol Q & -1 & Pol $\theta$ (Tebichi) & At4g32700 & $\begin{array}{l}\text { DNA polymerase } \\
\text { DNA end processing }\end{array}$ \\
\hline
\end{tabular}

${ }^{1}$ No yeast or Arabidopsis equivalent has been identified.

During the c-NHEJ pathway, DSB is recognized and bound by a Ku70/80 heterodimer to initiate the NHEJ repair [51]. The crystal structure of the human Ku heterodimer shows that the Ku heterodimer forms a ring structure on DNA broken ends in a sequenceindependent manner [52]. $\mathrm{Ku}$ is an abundant protein that has an extraordinary affinity for dsDNA ends allowing it to quickly localize to DSBs [51,53]. The binding of $\mathrm{Ku} 70 / 80$ could protect the DSB ends from end resection, followed by the recruitment of other factors to perform end processing. Therefore, more NHEJ factors are subsequently recruited to perform end processing, including DNA-PKcs, Artemis, polynucleotide kinase/phosphatase (PNKP), the gap-filling DNA polymerases mu (Pol $\mu$ ) and lambda $(\operatorname{Pol} \lambda)$, and the Mre11/Rad50/Nbs1 (MRN) complex. Arabidopsis Pol $\lambda$ promotes DNA end processing in association with the XRCC4 and Ligase 4 [54]. The Ligase 4-XRCC4 complex executes final ligation of the broken ends [55].

In the absence of the Ku complex, human and plant cells still can accomplish endjoining by alternative pathways (Figure 2). The a-NHEJ pathways require elements of HR end-resection machinery, and is often associated with short tracts of microhomology different from c-NHEJ. The molecular mechanism of a-NHEJ initiation remains unclear, although both the PARP1 and the MRN complex appear to play important roles [56]. PARP1 has been well described as an important player of the BER/SSBR pathway responsible for the recruitment of the XRCC1-Ligase3 complex to stimulate repair [57]. PARP1 has been reported to compete for free DNA ends with Ku and to interact with ATM [58,59]. Therefore, PARP1 may contribute to the early damage response and is supposed to serve as a platform at the broken end, to recruit other factors. Our early results confirmed that the Arabidopsis homologs AtPARP1 and AtPARP2 are also involved in MMEJ [60]. Ku inhibits end resection, and in the absence of $\mathrm{Ku}$, the MRN complex and the MRN-interacting C-terminal-binding interacting protein (CtIP) probably work together to mediate DSB resection in a-NHEJ [61]. The knockdown of Mre11 by siRNA decreased the frequency of a-NHEJ significantly 
without affecting the efficiency of c-NHEJ, suggesting that a-NHEJ repair of DNA DSBs requires Mre11 specifically [62]. The knockout of CtIP also results in a significant reduction in a-NHEJ $[63,64]$. Human Pol $\lambda$ and Pol $\beta$ assist MMEJ using terminal microhomology regions [65], and the interaction between PNKP and XRCC1 [66] suggests that they may engage in end processing during a-NHEJ. Furthermore, Polymerase $\theta$ (encoded by the Polq gene) which belongs to the DNA polymerase A family, plays an important role in the end processing process and is the key factor in TMEJ [48]. In studies on mus308, the Drosophila melanogaster homolog of Polq, McVey and his co-workers were the first to identify Pol $\theta$ as a factor in the a-NHEJ pathways of DSB repair [67]. Subsequently, the role of Pol $\theta$ in a-NHEJ/MMEJ has been characterized in several organisms. Biochemical studies have shown that the polymerase domain of Pol $\theta$ is able to independently carry out all of the major stages of MMEJ in vitro [68]. a-NHEJ is facilitated by sequence microhomology, which is an important signature of Pol $\theta$-mediated end-joining. Pol $\theta$ can use a minimum of $2 \mathrm{bp}$ and, optimally, $4 \mathrm{bp}$ microhomology for efficient and processive DNA synthesis [69]. A second feature of TMEJ is the production of templated DNA insertions at the DSB repair junction, which can arise from sequences directly adjacent to the resected ends or other chromosomes. In addition, it has been shown that Pol $\theta$ is able to favor the a-NHEJ, by employing its ATPase activity to counteract RPA binding and promote the annealing of resected DNA substrates [70]. Recently, TMEJ has moved to the forefront of a-NHEJ, and has been raised as an indispensable player in controlling genome stability [71]. However, whether TMEJ now takes the place of MMEJ or if TMEJ is a third pathway in addition to MMEJ remains to be further determined, although several reports show that TMEJ also functions in the presence of other DSB repair pathways [72-75]. In plants, the Arabidopsis thaliana ortholog TEBICHI (Teb) is involved in DNA replication, recombination and gene expression [76]. A recent report demonstrated that Arabidopsis Pol $\theta$ participates in the repair of replication-associated DNA damage [77]. In mammalian cells, the XRCC1-Ligase3 complex seems to contribute to DSB ligation in the a-NHEJ pathway $[78,79]$. Since plants are lacking a Ligase 3 homolog, there must be other factors to take over ligation during a-NHEJ in plants. One of the candidates is SSB repair factor Ligase 1, which is associated in the a-NHEJ repair pathway in Arabidopsis [80]. Ligase 1 displays functional redundancy with Ligase 3 and might cooperate in a-NHEJ in mammals [81,82].

\section{DSB Repair Pathway and Agrobacterium-Mediated T-DNA Integration}

Agrobacterium tumefaciens is nowadays employed as a vector to create genetically modified plants. During the process of Agrobacterium-mediated genetic transformation, T-DNA is transferred from its tumor-inducing plasmid to the host cell's nuclear genome. T-DNA is at random positions in the plant genome, which may lead to mutation and position effects altering the expression of the transgenes. Therefore, there is great interest in developing methods for the controlled and targeted integration of T-DNA. In yeast, this can be accomplished by providing a segment of yeast-homologous DNA in the T-DNA. The HR machinery of yeast then mediates integration at the homologous site [83]. In plants, homologous recombination can occur between a chromosomal locus and a homologous T-DNA introduced via Agrobacterium [84], but only with a very low efficiency. Two possible models have been recommended for T-DNA integration $[85,86]$. In the strand-invasion model, T-DNA integration counts on the microhomology between T-DNA and plant DNA sequences. Single-stranded T-DNA is expected to facilitate the integration [87-89]. In the DNA DSB repair model, the single-stranded T-DNA is first converted to a double-stranded T-DNA, whereafter this double strand form integrates into the genome at DSB sites [90]. This was supported by the fact that DSBs are preferential targets for T-DNA integration and that T-DNA can be cut by a restriction enzyme before integration [91,92]. Furthermore, by using CRISPR technology to induce DSBs, a recent finding demonstrated that T-DNA was inserted into the break sites of CRISPR/Cas9 targets with high frequency [93]. In addition, given that the microbial pathogens are capable of triggering host DNA double-strand 
breaks [94], the inoculation by Agrobacterium perhaps induces DSBs in host plant genomes as well, to favor the integration of T-DNA.

Although T-DNA integration has been studied for decades, its molecular mechanism has remained unclear. It should be certain that host proteins, rather than Agrobacterium proteins, are responsible for the T-DNA integration in plant genomes, which refer to the plant DNA-repair pathways. Therefore, the NHEJ pathways which have been described above are proposed to play an essential role in the integration of T-DNA to the plant genome. Earlier reports indicated that yeast (S. cerevisiae) T-DNA integration depends on NHEJ proteins, such as Ku70 and DNA ligase 4 [95,96]. NHEJ mutants in Arabidopsis were later investigated for T-DNA integration in plants. However, different research groups had conflicting results on plant T-DNA integration and revealed either no or limited negative effects [96-99]. When the multiple DNA-repair pathways were disabled at the same time, T-DNA integration was severely compromised but remained possible [100-102]. Nevertheless, disruption of these known repair pathways did not eliminate the end-joining, suggesting that plant T-DNA integration was mediated by other unknown proteins and pathways. Indeed, a recent study from van Kregten et al. presented that the Arabidopsis Pol $\theta$ is crucial for T-DNA integration [74]. Arabidopsis Pol $\theta$ mutants are completely recalcitrant to Agrobacterium-mediated transformation. As mentioned above, Pol $\theta$ is recognized as an important factor in the a-NHEJ of DSB repair due to its special properties of microhomology usage and template switching. These characteristics are also frequent at the T-DNA integration junctions [74,103]. 'Filler DNA' sequences, or alleged templated insertions, are often found at junctions and genomic sequences, which are often templated from the flank. Pol $\theta$ is proposed to extend paired $3^{\prime}$ overhangs at DNA synapses and use the opposing overhang as a template in trans to stabilize the DNA synapse [68]. Thus, the T-DNA left border (LB), which is a $3^{\prime}$ end, is the preferred substrate for Pol $\theta$ to be minimally base-paired with a $3^{\prime}$ end of DSB in the plant genome. Taken together, TMEJ mediates the capture of T-DNA into a DSB, providing an answer for how the T-DNA left border (LB) attaches to the plant genome (Figure 3).

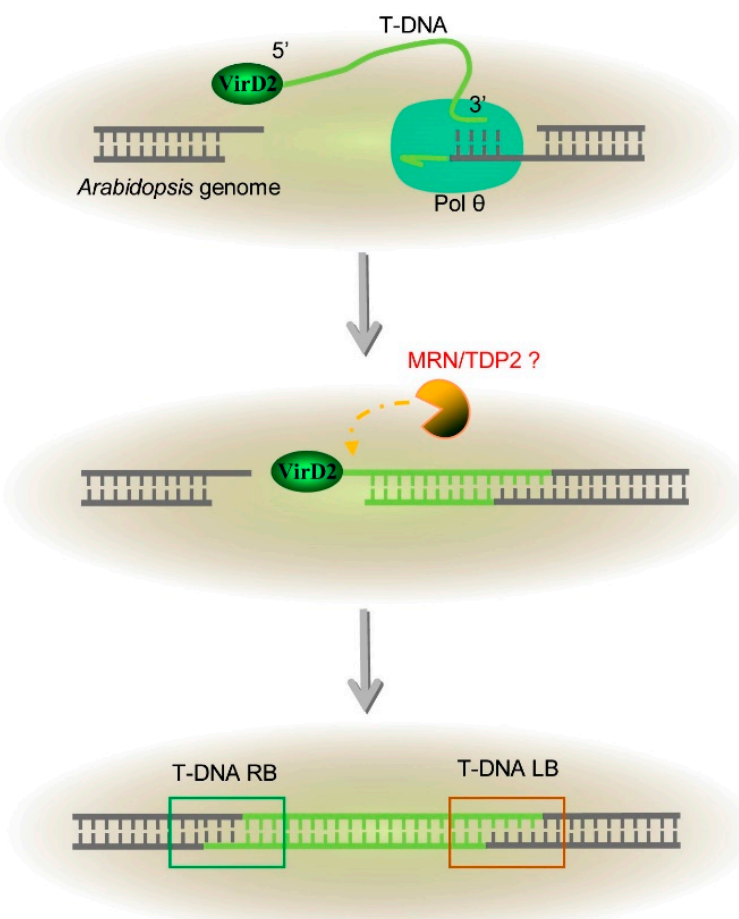

Figure 3. Simplified model of T-DNA integration: polymerase $\theta$ is required for capture of the T-DNA's $3^{\prime}$ end; MRN or TDP2 helps to remove VirD2 for genomic capture of the $5^{\prime}$ end. 
Even though TMEJ explains the connecting of the T-DNA $3^{\prime}$ end of the integration progress, questions remain about the attachment of the T-DNA $5^{\prime}$ right border (RB). More recently, Nishizawa-Yokoi et al. showed that mutation of Pol $\theta$ in rice allowed stable transformation with low frequency, in which the junction fragments displayed similar characteristics to those of the wild-type plants, arguing for genes other than Pol $\theta$ in rice may also be responsible for T-DNA integration [104]. Notably, our recent results revealed that plant T-DNA integration requires Mre11 or TDP2 to remove the end protection from VirD2, to allow the capture of the T-DNA 5' end in Arabidopsis [105]; this may fill a major gap in our understanding of T-DNA integration in plants.

\section{DSB Repair Pathway and Gene Targeting}

Gene targeting (GT) is a powerful genetic technique to change or replace endogenous genes depending on homologous recombination, which has been widely used to study gene function. Several approaches were established to select and detect GT events, including gene-specific selection (GSS) and positive-negative selection (PNS). In GSS schemes, an endogenous target gene is replaced by a copy of the same gene with a selectable mutation. In PNS schemes, the selection of homologous recombination relies on positive and negative selectable markers installed within and outside the homologous sequence, respectively. The PNS-based approach has proven to be very successful and is also used in plant species such as rice and Arabidopsis. GT can be achieved efficiently, especially in yeast and a few other organisms. However, GT is usually inefficient in the cells of multicellular eukaryotes, especially in those of plants, due to a much lower efficiency of HR than NHEJ [106]. The observed GT frequencies from multiple studies in plants are low and often in the $10^{-2}$ to $10^{-3}$ range [107-111]. In order to establish a feasible tool for GT, two options were tested to enhance the GT frequency based on the mechanism of HR. The first option was to promote the HR pathway by either increasing the synthesis of proteins involved in HR [112,113] or by inhibiting the synthesis of proteins involved in the NHEJ pathway [100]. The prevention of fungi NHEJ by deletion of Ku or Lig4 resulted in very efficient GT $[96,114,115]$. In plants, several reports show that GT efficiency can also be increased by blocking the NHEJ pathway or enhancing the HR pathway [116-118]. However, recent studies in mammalian and Arabidopsis indicate that the deficiency of Pol $\theta$ does not increase GT events $[119,120]$. Another approach was to enhance GT by inducing genomic DSBs at the target site, which became possible by the development of different classes of artificial nucleases (see below). In this way, the frequency of GT was increased significantly in different organisms, including plants [121-124]. GT was also achieved in Arabidopsis thaliana by expression of a site-specific endonuclease that cuts not only within the target, but also the chromosomal transgenic donor (in planta GT), leading to an excised targeting vector in each plant cell [125]. Due to recent developments, especially the application of a CRISPR/Cas nuclease system, several groups have achieved efficiency improvements of GT in plants. For instance, the group of Puchta used an egg-cell-specific promoter of the SaCas9 nuclease, which enabled them to sufficiently enhance GT efficiencies up to $1-6 \%$ in Arabidopsis [126]. Voytas and his co-workers employed geminivirus-based DNA replicons combined with Cas9, resulting in GT frequencies of $\sim 1 \%$ in wheat [127]. The group of Levy also found that GT efficiency was strongly increased by using geminiviral replicons and a Cas9 system in tomato, with $25 \%$ in the T0 plant [128]. In addition, other works showed high GT rates of $9.1 \%$ in Arabidopsis and $8 \%$ in rice by using Cas9 and Cpf1, respectively, although they were based on small numbers of GT events $[129,130]$. Furthermore, several novel approaches seem to be applicable in plants to improve GT efficiency. The enhancing homology-directed repair (HDR) efficiency was observed by fusing Cas9 with a donor DNA sequence, which ultimately brought the donor DNA into close proximity to the DSB sites [131-133]. Moreover, it was interesting to find that the Cas9-CtIP fusion efficiently stimulated HDR after Cas9-mediated DNA cleavage [134]. Taken together, these findings might open a promising avenue for a higher efficiency of GT with the CRISPR/Cas9 system. 


\section{Strategies for DSB Induction}

As DNA recombination events, including transgene integration and gene targeting, are increased at break sites in the genome, it has been a strategy to induce local DNA breaks to stimulate these events. Ionizing radiation (X-ray) and genotoxic chemicals (Bleomycin, MMS, etc.) were initially used to induce such DNA breaks, but as they affect the genome in an uncontrolled manner and cause mutation, this was not very successful.

Site-specific nucleases have been developed by which DSBs can be induced at a preferred site in the genome. The advent of meganucleases, such as SceI, for the first time offered the possibility to induce a DSB at a specific site(s) in a large genome. Such a local break inspired a significant increase in DNA integration [90] and in gene targeting [135]. Since then, three classes of nucleases have been used extensively: zinc finger nucleases (ZFNs), transcription activator-like effector nucleases (TALENs) and the CRISPR/Cas (for 'clustered regularly interspersed short palindromic repeats/CRISPR associated') system.

ZFNs consist of zinc finger arrays fused to the nuclease domain of the type II restriction enzyme FokI. Each zinc finger typically recognizes three nucleotides, and engineered fingers have been combined to recognize specific longer DNA sequences. ZFNs function as a dimer to produce a DSB within the spacer between the binding sites of two ZFN monomers. ZFN-mediated gene modification has been reported in different eukaryotic organisms [121] and also in Arabidopsis [109,116,123]. Like ZFNs, TALENs are composed of DNA-binding domains and a FokI nuclease domain. Each binding domain includes a variable number of amino acid repeats, which are able to specifically recognize a single base pair of DNA [136]. TALENs and ZFNs make DSBs with $5^{\prime}$ overhangs. TALENs are considered to be more efficient, specific and reproducible, because TALENs are less affected by the context of targeting sequences than ZFNs, as shown in yeast [137], human [138] and Arabidopsis [139].

In 2012, an RNA-guided CRISPR/Cas nuclease system was described for inducing DNA DSBs at specific genomic loci [140]. CRISPR/Cas originates from a microbial adaptive immune system that uses RNA-guided nucleases to cleave the foreign invading sequences. The CRISPR/Cas9 used for DSB induction in eukaryote organisms is based on bacterial type II CRISPR/Cas systems, consisting of CRISPR-associated protein Cas9 and a single guide RNA chimera (sgRNA), which was engineered from the tracrRNA and crRNA [140]. Guided by the sgRNA via base-pairing to the target DNA sequence, both strands of the target DNA are cleaved by two endonuclease domains (HNH- and RuvC-like domains) of the Cas9 protein. The cleavage locations are also determined by a protospacer-adjacent motif (PAM) which is juxtaposed to the complementary region in the target DNA [140]. Furthermore, the CRISPR/Cas12a, formally known as Cpf1 belonging to the Class 2 type V CRISPR/Cas system, has emerged as an alternative and promising gene-editing tool with an efficiency that is at least comparable to the CRISPR/Cas9 [141,142]. Cas12a creates staggered DNA double-stranded break ends, while Cas9 produces blunt ends. The CRISPR/Cas system is markedly easier to design by changing the guide RNA sequence, compared to ZFNs and TALENs. It is highly specific and efficient for a vast number of cell types and organisms. Thus, CRISPR has quickly become a standard technique in genome engineering since its discovery. During the past ten years, the CRISPR technique has been applied successfully in various organisms and has shown incredibly fast development.

\section{Concluding Remarks and Future Perspectives}

Although an increasing number of proteins engaged in DNA-repair pathways have been analyzed, and their interactions investigated, in the past few decades, the repair mechanisms are not fully understood at present and require more in-depth studies. The mechanisms evolved to repair DSBs are highly conserved between organisms; however, studies in plants lag behind. These repair pathways contribute to T-DNA integration and targeted DNA insertion. The understanding of the DSB repair mechanism is beneficial to develop precise genome modification approaches, which are extremely valuable for crop plants. Furthermore, the CRISPR/Cas-mediated genome-editing tool was employed in various plants successfully in the last decade. This application not only improves our 
ability to deal with specific issues in fundamental research, but also adapts to creating germplasms of crop species with desired traits, and to enhancing global food security and sustainable agriculture. As we gain a deeper understanding of repair mechanisms and the improvement of nuclease-based technology, we can expect even more diversification and high-efficiency genome editing tools in the near future.

Author Contributions: H.S. and Z.L. contributed to writing the manuscript. All authors have read and agreed to the published version of the manuscript.

Funding: This work was funded by the Natural Science Foundation of Shandong Province, grant number ZR2020MC058, The Introduction and Cultivation Plan for Young Innovative Talents of Colleges and Universities by the Education Department of Shandong Province, and the Youth Innovation Technology Project of Higher School in Shandong Province, grant number 2020KJF013.

Institutional Review Board Statement: Not applicable.

Informed Consent Statement: Not applicable.

Data Availability Statement: Not applicable.

Acknowledgments: The authors thank Sylvia de Pater and Paul JJ Hooykaas for supervision on an earlier version of this manuscript.

Conflicts of Interest: The authors declare no conflict of interest.

\section{References}

1. Khanna, K.K.; Jackson, S.P. DNA double-strand breaks: Signaling, repair and the cancer connection. Nat. Genet. 2001, 27, 247-254. [CrossRef]

2. Manova, V.; Gruszka, D. DNA damage and repair in plants-From models to crops. Front. Plant Sci. 2015, 6, 1-26. [CrossRef]

3. Hayut, S.F.; Bessudo, C.M.; Levy, A.A. Targeted recombination between homologous chromosomes for precise breeding in tomato. Nat. Commun. 2017, 8, 1-9. [CrossRef]

4. Siebert, R.; Puchta, H. Efficient repair of genomic double-strand breaks by homologous recombination between directly repeated sequences in the plant genome. Plant Cell 2002, 14, 1121-1131. [CrossRef]

5. Stinson, B.M.; Loparo, J.J. Repair of DNA Double-Strand Breaks by the Nonhomologous End Joining Pathway. Annu. Rev. Biochem. 2021, 90, 137-164. [CrossRef]

6. Puchta, H. The repair of double-strand breaks in plants: Mechanisms and consequences for genome evolution. J. Exp. Bot. 2005, 56, 1-14. [CrossRef]

7. Spampinato, C.P. Protecting DNA from errors and damage: An overview of DNA repair mechanisms in plants compared to mammals. Cell. Mol. Life Sci. 2017, 74, 1693-1709. [CrossRef]

8. Block, W.D.; Yu, Y.; Lees-Miller, S.P. Phosphatidyl inositol 3-kinase-like serine/threonine protein kinases (PIKKs) are required for DNA damage-induced phosphorylation of the $32 \mathrm{kDa}$ subunit of replication protein A at threonine 21. Nucleic Acids Res. 2004, 32, 997-1005. [CrossRef]

9. Falck, J.; Coates, J.; Jackson, S.P. Conserved modes of recruitment of ATM, ATR and DNA-PKcs to sites of DNA damage. Nature 2005, 434, 605-611. [CrossRef]

10. Shiloh, Y. The ATM-mediated DNA-damage response: Taking shape. Trends Biochem. Sci. 2006, 31, 402-410. [CrossRef]

11. Matsuoka, S.; Ballif, B.A.; Smogorzewska, A.; McDonald, E.R.; Hurov, K.E.; Luo, J.; Bakalarski, C.E.; Zhao, Z.; Solimini, N.; Lerenthal, Y.; et al. ATM and ATR substrate analysis reveals extensive protein networks responsive to DNA damage. Science 2007, 316, 1160-1166. [CrossRef]

12. Blackford, A.N.; Jackson, S.P. ATM, ATR, and DNA-PK: The Trinity at the Heart of the DNA Damage Response. Mol. Cell 2017, 66, 801-817. [CrossRef]

13. Tomimatsu, N.; Mukherjee, B.; Burma, S. Distinct roles of ATR and DNA-PKcs in triggering DNA damage responses in ATMdeficient cells. EMBO Rep. 2009, 10, 629-635. [CrossRef]

14. Meyer, B.; Voss, K.O.; Tobias, F.; Jakob, B.; Durante, M.; Taucher-Scholz, G. Clustered DNA damage induces pan-nuclear H2AX phosphorylation mediated by ATM and DNA-PK. Nucleic Acids Res. 2013, 41, 6109-6118. [CrossRef]

15. White, D.E.; Negorev, D.; Peng, H.; Ivanov, A.V.; Maul, G.G.; Rauscher, F.J. KAP1, a novel substrate for PIKK family members, colocalizes with numerous damage response factors at DNA lesions. Cancer Res. 2006, 66, 11594-11599. [CrossRef]

16. Lu, H.; Saha, J.; Beckmann, P.J.; Hendrickson, E.A.; Davis, A.J. DNA-PKcs promotes chromatin decondensation to facilitate initiation of the DNA damage response. Nucleic Acids Res. 2019, 47, 9467-9479. [CrossRef]

17. Garcia, V.; Bruchet, H.; Camescasse, D.; Granier, F.; Bouchez, D.; Tissier, A. AtATM is essential for meiosis and the somatic response to DNA damage in plants. Plant Cell 2003, 15, 119-132. [CrossRef] 
18. Culligan, K.M.; Robertson, C.E.; Foreman, J.; Doerner, P.; Britt, A.B. ATR and ATM play both distinct and additive roles in response to ionizing radiation. Plant J. 2006, 48, 947-961. [CrossRef]

19. Cools, T.; De Veylder, L. DNA stress checkpoint control and plant development. Curr. Opin. Plant Biol. 2009, 12, 23-28. [CrossRef]

20. Hu, Z.; Cools, T.; De Veylder, L. Mechanisms Used by Plants to Cope with DNA Damage. Annu. Rev. Plant Biol. 2016, 67, 439-462. [CrossRef]

21. Yoshiyama, K.O.; Kobayashi, J.; Ogita, N.; Ueda, M.; Kimura, S.; Maki, H.; Umeda, M. ATM-mediated phosphorylation of SOG1 is essential for the DNA damage response in Arabidopsis. EMBO Rep. 2013, 14, 817-822. [CrossRef]

22. Bourbousse, C.; Vegesna, N.; Law, J.A. SOG1 activator and MYB3R repressors regulate a complex DNA damage network in Arabidopsis. Proc. Natl. Acad. Sci. USA 2018, 115, E12453-E12462. [CrossRef]

23. Ogita, N.; Okushima, Y.; Tokizawa, M.; Yamamoto, Y.Y.; Tanaka, M.; Seki, M.; Makita, Y.; Matsui, M.; Okamoto-Yoshiyama, K.; Sakamoto, T.; et al. Identifying the target genes of SUPPRESSOR OF $\gamma$ RESPONSE 1, a master transcription factor controlling DNA damage response in Arabidopsis. Plant J. 2018, 94, 439-453. [CrossRef]

24. De Schutter, K.; Joubes, J.; Cools, T.; Verkest, A.; Corellou, F.; Babiychuk, E.; Van Der Schueren, E.; Beeckman, T.; Kushnir, S.; Inze, D.; et al. Arabidopsis WEE1 kinase controls cell cycle arrest in response to activation of the DNA integrity checkpoint. Plant Cell 2007, 19, 211-225. [CrossRef]

25. Pan, T.; Qin, Q.; Nong, C.; Gao, S.; Wang, L.; Cai, B.; Zhang, M.; Wu, C.; Chen, H.; Li, T.; et al. A novel WEE1 pathway for replication stress responses. Nat. Plants 2021, 7, 209-218. [CrossRef]

26. Horvath, B.M.; Kourova, H.; Nagy, S.; Nemeth, E.; Magyar, Z.; Papdi, C.; Ahmad, Z.; Sanchez-Perez, G.F.; Perilli, S.; Blilou, I.; et al. Arabidopsis RETINOBLASTOMA RELATED directly regulates DNA damage responses through functions beyond cell cycle control. EMBO J. 2017, 36, 1261-1278. [CrossRef]

27. Biedermann, S.; Harashima, H.; Chen, P.; Heese, M.; Bouyer, D.; Sofroni, K.; Schnittger, A. The retinoblastoma homolog RBR 1 mediates localization of the repair protein RAD 51 to DNA lesions in Arabidopsis. EMBO J. 2017, 36, 1279-1297. [CrossRef]

28. Nisa, M.U.; Huang, Y.; Benhamed, M.; Raynaud, C. The plant DNA damage response: Signaling pathways leading to growth inhibition and putative role in response to stress conditions. Front. Plant Sci. 2019, 10, 1-12. [CrossRef]

29. Heyer, W.-D.; Ehmsen, K.T.; Liu, J. Regulation of homologous recombination in eukaryotes. Annu. Rev. Genet. 2010, 44, 113-139. [CrossRef]

30. Serra, H.; Da Ines, O.; Degroote, F.; Gallego, M.E.; White, C.I. Roles of XRCC2, RAD51B and RAD51D in RAD51-Independent SSA Recombination. PLoS Genet. 2013, 9, e1003971. [CrossRef]

31. Schuermann, D.; Molinier, J.; Fritsch, O.; Hohn, B. The dual nature of homologous recombination in plants. Trends Genet. 2005, 21, 172-181. [CrossRef]

32. Mimitou, E.P.; Symington, L.S. DNA end resection-Unraveling the tail. DNA Repair 2011, 10, 344-348. [CrossRef] [PubMed]

33. Owalczykowski, S.T.C.K. DNA annealing by Rad52 Protein is stimulated by specific interaction with the complex of replication protein A and single-stranded DNA. Proc. Natl. Acad. Sci. USA 1998, 95, 6049-6054.

34. Sugiyama, T.; Zaitseva, E.M.; Kowalczykowski, S.C. A Single-stranded DNA-binding Protein Is Needed for Efficient Presynaptic Complex Formation by the Saccharomyces cerevisiae Rad51 Protein. J. Biol. Chem. 1997, 272, 7940-7945. [CrossRef] [PubMed]

35. Edlinger, B.; Schlögelhofer, P. Have a break: Determinants of meiotic DNA double strand break (DSB) formation and processing in plants. J. Exp. Bot. 2011, 62, 1545-1563. [CrossRef] [PubMed]

36. Mannuss, A.; Trapp, O.; Puchta, H. Gene regulation in response to DNA damage. Biochim. Biophys. Acta-Gene Regul. Mech. 2012, 1819, 154-165. [CrossRef]

37. Mazin, A.V.; Alexeev, A.A.; Kowalczykowski, S.C. A novel function of Rad54 protein. Stabilization of the Rad51 nucleoprotein filament. J. Biol. Chem. 2003, 278, 14029-14036. [CrossRef]

38. Wolner, B.; Peterson, C.L. ATP-dependent and ATP-independent roles for the Rad54 chromatin remodeling enzyme during recombinational repair of a DNA double strand break. J. Biol. Chem. 2005, 280, 10855-10860. [CrossRef]

39. Wu, Y.; Sugiyama, T.; Kowalczykowski, S.C. DNA annealing mediated by Rad52 and Rad59 proteins. J. Biol. Chem. 2006, 281, 15441-15449. [CrossRef]

40. Baudat, F.; de Massy, B. Regulating double-stranded DNA break repair towards crossover or non-crossover during mammalian meiosis. Chromosome Res. 2007, 15, 565-577. [CrossRef]

41. Moynahan, M.E.; Jasin, M. Mitotic homologous recombination maintains genomic stability and suppresses tumorigenesis. Nat. Rev. Mol. Cell Biol. 2010, 11, 196-207. [CrossRef] [PubMed]

42. Prakash, R.; Satory, D.; Dray, E.; Papusha, A.; Scheller, J.; Kramer, W.; Krejci, L.; Klein, H.; Haber, J.E.; Sung, P.; et al. Yeast Mph1 helicase dissociates Rad51-made D-loops: Implications for crossover control in mitotic recombination. Genes Dev. 2009, 23, 67-79. [CrossRef] [PubMed]

43. Wu, Y.; Kantake, N.; Sugiyama, T.; Kowalczykowski, S.C. Rad51 protein controls Rad52-mediated DNA annealing. J. Biol. Chem. 2008, 283, 14883-14892. [CrossRef] [PubMed]

44. Lydeard, J.R.; Jain, S.; Yamaguchi, M.; Haber, J.E. Break-induced replication and telomerase-independent telomere maintenance require Pol32. Nature 2007, 448, 820-823. [CrossRef] [PubMed]

45. Schubert, I.; Schubert, V.; Fuchs, J. No evidence for "break-induced replication" in a higher plant-But break-induced conversion may occur. Front. Plant Sci. 2011, 2, 1-6. [CrossRef] [PubMed] 
46. Lieber, M.R. The mechanism of double-strand DNA break repair by the nonhomologous DNA end joining pathway. Annu. Rev. Biochem. 2010, 79, 181-211. [CrossRef]

47. McVey, M.; Lee, S.E. MMEJ repair of double-strand breaks (director's cut): Deleted sequences and alternative endings. Trends Genet. 2008, 24, 529-538. [CrossRef]

48. Ramsden, D.A.; Carvajal-Garcia, J.; Gupta, G.P. Mechanism, cellular functions and cancer roles of polymerase-theta-mediated DNA end joining. Nat. Rev. Mol. Cell Biol. 2022, 23, 125-140. [CrossRef]

49. Van Gent, D.C.; van der Burg, M. Non-homologous end-joining, a sticky affair. Oncogene 2007, 26, 7731-7740. [CrossRef]

50. Shen, H.; Strunks, G.D.; Klemann, B.J.P.M.; Hooykaas, P.J.J.; de Pater, S. CRISPR/Cas9-Induced Double-Strand Break Repair in Arabidopsis Nonhomologous End-Joining Mutants. G3 Genes Genomes Genet. 2017, 7, 193-202. [CrossRef]

51. Waterworth, W.M.; Drury, G.E.; Bray, C.M.; West, C.E. Repairing breaks in the plant genome: The importance of keeping it together. New Phytol. 2011, 192, 805-822. [CrossRef] [PubMed]

52. Walker, J.R.; Corpina, R.A.; Goldberg, J. Structure of the Ku heterodimer bound to DNA and its implications for double-strand break repair. Nature 2001, 412, 607-614. [CrossRef] [PubMed]

53. Valuchova, S.; Fulnecek, J.; Prokop, Z.; Stolt-Bergner, P.; Janouskova, E.; Hofr, C.; Riha, K. Protection of arabidopsis blunt-ended telomeres is mediated by a physical association with the ku heterodimer. Plant Cell 2017, 29, 1533-1545. [CrossRef]

54. Roy, S.; Choudhury, S.R.; Sengupta, D.N.; Das, K.P. Involvement of AtPol $\lambda$ in the repair of high salt- and DNA cross-linking agent-induced double strand breaks in Arabidopsis. Plant Physiol. 2013, 162, 1195-1210. [CrossRef] [PubMed]

55. West, C.E.; Waterworth, W.M.; Jiang, Q.; Bray, C.M. Arabidopsis DNA ligase IV is induced by $\gamma$-irradiation and interacts with an Arabidopsis homologue of the double strand break repair protein XRCC4. Plant J. 2000, 24, 67-78. [CrossRef]

56. Deriano, L.; Roth, D.B. Modernizing the nonhomologous end-joining repertoire: Alternative and classical NHEJ share the stage. Annu. Rev. Genet. 2013, 47, 433-455. [CrossRef] [PubMed]

57. Caldecott, K.W. Single-strand break repair and genetic disease. Nat. Rev. Genet. 2008, 9, 619-631. [CrossRef] [PubMed]

58. Haince, J.F.; McDonald, D.; Rodrigue, A.; Dery, U.; Masson, J.Y.; Hendzel, M.J.; Poirier, G.G. PARP1-dependent kinetics of recruitment of MRE11 and NBS1 proteins to multiple DNA damage sites. J. Biol. Chem. 2008, 283, 1197-1208. [CrossRef]

59. Aguilar-quesada, R.; Muñoz-gámez, J.A.; Martín-Oliva, D.; Peralta, A.; Valenzuela, M.T.; Matínez-Romero, R.; Quiles-pérez, R.; Menissier-de Murcia, J.; de Murcia, G.; Ruiz de Almodóvar, M.; et al. Interaction between ATM and PARP-1 in response to DNA damage and sensitization of ATM deficient cells through PARP inhibition. BMC Mol. Biol. 2007, 8, 29. [CrossRef]

60. Jia, Q.; Den Dulk-Ras, A.; Shen, H.; Hooykaas, P.J.J.; de Pater, S. Poly(ADP-ribose)polymerases are involved in microhomology mediated back-up non-homologous end joining in Arabidopsis thaliana. Plant Mol. Biol. 2013, 82, 339-351. [CrossRef]

61. Uanschou, C.; Siwiec, T.; Pedrosa-Harand, A.; Kerzendorfer, C.; Sanchez-Moran, E.; Novatchkova, M.; Akimcheva, S.; Woglar, A.; Klein, F.; Schlögelhofer, P. A novel plant gene essential for meiosis is related to the human CtIP and the yeast COM1/SAE2 gene. EMBO J. 2007, 26, 5061-5070. [CrossRef] [PubMed]

62. Zhuang, J.; Jiang, G.; Willers, H.; Xia, F. Exonuclease function of human Mre11 promotes deletional nonhomologous end joining. J. Biol. Chem. 2009, 284, 30565-30573. [CrossRef] [PubMed]

63. Lee-Theilen, M.; Matthews, A.J.; Kelly, D.; Zheng, S.; Chaudhuri, J. CtIP promotes microhomology-mediated alternative end joining during class-switch recombination. Nat. Struct. Mol. Biol. 2011, 18, 75-79. [CrossRef]

64. Zhang, Y.; Jasin, M. An essential role for CtIP in chromosomal translocation formation through an alternative end-joining pathway. Nat. Struct. Mol. Biol. 2011, 18, 80-84. [CrossRef] [PubMed]

65. Crespan, E.; Czabany, T.; Maga, G.; Hübscher, U. Microhomology-mediated DNA strand annealing and elongation by human DNA polymerases $\lambda$ and $\beta$ on normal and repetitive DNA sequences. Nucleic Acids Res. 2012, 40, 5577-5590. [CrossRef]

66. Weinfeld, M.; Mani, R.S.; Abdou, I.; Aceytuno, R.D.; Glover, J.N.M. Tidying up loose ends: The role of polynucleotide kinase/phosphatase in DNA strand break repair. Trends Biochem. Sci. 2011, 36, 262-271. [CrossRef]

67. Chan, S.H.; Yu, A.M.; McVey, M. Dual roles for DNA polymerase theta in alternative end-joining repair of double-strand breaks in Drosophila. PLoS Genet. 2010, 6, e1001005. [CrossRef]

68. Kent, T.; Chandramouly, G.; McDevitt, S.M.; Ozdemir, A.Y.; Pomerantz, R.T. Mechanism of microhomology-mediated end-joining promoted by human DNA polymerase theta. Nat. Struct. Mol. Biol. 2015, 22, 230-237. [CrossRef]

69. He, P.; Yang, W. Template and primer requirements for DNA Pol $\theta$-mediated end joining. Proc. Natl. Acad. Sci. USA 2018, 115, 7747-7752. [CrossRef]

70. Mateos-Gomez, P.A.; Kent, T.; Deng, S.K.; Mcdevitt, S.; Kashkina, E.; Hoang, T.M.; Pomerantz, R.T.; Sfeir, A. The helicase domain

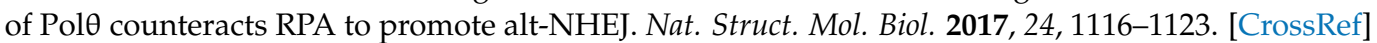

71. Schrempf, A.; Slyskova, J.; Loizou, J.I. Targeting the DNA Repair Enzyme Polymerase $\theta$ in Cancer Therapy. Trends Cancer 2021, 7, 98-111. [CrossRef] [PubMed]

72. Koole, W.; van Schendel, R.; Karambelas, A.E.; van Heteren, J.T.; Okihara, K.L.; Tijsterman, M. A Polymerase Theta-dependent repair pathway suppresses extensive genomic instability at endogenous G4 DNA sites. Nat. Commun. 2014, 5, 3216. [CrossRef] [PubMed]

73. Mateos-Gomez, P.A.; Gong, F.; Nair, N.; Miller, K.M.; Lazzerini-Denchi, E.; Sfeir, A. Mammalian polymerase $\theta$ promotes alternative NHEJ and suppresses recombination. Nature 2015, 518, 254-257. [CrossRef] [PubMed]

74. Van Kregten, M.; De Pater, S.; Romeijn, R.; Van Schendel, R.; Hooykaas, P.J.J.; Tijsterman, M. T-DNA integration in plants results from polymerase- $\theta$-mediated DNA repair. Nat. Plants 2016, 2, 16164. [CrossRef] 
75. Wyatt, D.W.; Feng, W.; Conlin, M.P.; Yousefzadeh, M.J.; Roberts, S.A.; Mieczkowski, P.; Wood, R.D.; Gupta, G.P.; Ramsden, D.A. Essential Roles for Polymerase $\theta$-Mediated End Joining in the Repair of Chromosome Breaks. Mol. Cell 2016, 63, 1-12. [CrossRef]

76. Inagaki, S.; Nakamura, K.; Morikami, A. A link among DNA replication, recombination, and gene expression revealed by genetic and genomic analysis of TEBICHI gene of Arabidopsis thaliana. PLoS Genet. 2009, 5, e1000613. [CrossRef]

77. Nisa, M.; Bergis, C.; Pedroza-Garcia, J.A.; Drouin-Wahbi, J.; Mazubert, C.; Bergounioux, C.; Benhamed, M.; Raynaud, C. The plant DNA polymerase theta is essential for the repair of replication-associated DNA damage. Plant J. 2021, 106, 1197-1207. [CrossRef]

78. Audebert, M.; Salles, B.; Calsou, P. Involvement of poly(ADP-ribose) polymerase-1 and XRCC1/DNA ligase III in an alternative route for DNA double-strand breaks rejoining. J. Biol. Chem. 2004, 279, 55117-55126. [CrossRef]

79. Simsek, D.; Brunet, E.; Wong, S.Y.W.; Katyal, S.; Gao, Y.; McKinnon, P.J.; Lou, J.; Zhang, L.; Li, J.; Rebar, E.J.; et al. DNA ligase III promotes alternative nonhomologous end-joining during chromosomal translocation formation. PLoS Genet. 2011, 7, e1002080. [CrossRef]

80. Waterworth, W.M.; Kozak, J.; Provost, C.M.; Bray, C.M.; Angelis, K.J.; West, C.E. DNA ligase 1 deficient plants display severe growth defects and delayed repair of both DNA single and double strand breaks. BMC Plant Biol. 2009, 9, 79. [CrossRef]

81. Arakawa, H.; Bednar, T.; Wang, M.; Paul, K.; Mladenov, E.; Bencsik-Theilen, A.A.; Iliakis, G. Functional redundancy between DNA ligases I and III in DNA replication in vertebrate cells. Nucleic Acids Res. 2012, 40, 2599-2610. [CrossRef] [PubMed]

82. Paul, K.; Wang, M.; Mladenov, E.; Bencsik-Theilen, A.; Bednar, T.; Wu, W.; Arakawa, H.; Iliakis, G. DNA ligases I and III cooperate in alternative non-homologous end-joining in vertebrates. PLoS ONE 2013, 8, e59505. [CrossRef] [PubMed]

83. Bundock, P.; den Dulk-Ras, A.; Beijersbergen, A.; Hooykaas, P.J. Trans-kingdom T-DNA transfer from Agrobacterium tumefaciens to Saccharomyces cerevisiae. EMBO J. 1995, 14, 3206-3214. [CrossRef] [PubMed]

84. Offringa, R.; de Groot, M.J.; Haagsman, H.J.; Does, M.P.; van den Elzen, P.J.; Hooykaas, P.J. Extrachromosomal homologous recombination and gene targeting in plant cells after Agrobacterium mediated transformation. EMBO J. 1990, 9, 3077-3084. [CrossRef] [PubMed]

85. Tzfira, T.; Li, J.; Lacroix, B.; Citovsky, V. Agrobacterium T-DNA integration: Molecules and models. Trends Genet. 2004, 20, 375-383. [CrossRef]

86. Gelvin, S.B. Plant Proteins Involved in Agrobacterium -Mediated Genetic Transformation. Annu. Rev. Phytopathol. 2010, 48, 45-68. [CrossRef]

87. Rodenburg, K.W.; de Groot, M.J.; Schilperoort, R.A.; Hooykaas, P.J. Single-stranded DNA used as an efficient new vehicle for transformation of plant protoplasts. Plant Mol. Biol. 1989, 13, 711-719. [CrossRef]

88. Gheysen, G.; Villarroel, R.; Van Montagu, M. Illegitimate recombination in plants: A model for T-DNA integration. Genes Dev. 1991, 5, 287-297. [CrossRef]

89. Mayerhofer, R.; Koncz-kalman, Z.; Nawrath, C.; Bakkeren, G.; Crameri, A.; Angelis, K.; Redei, G.P.; Schell, J.; Hohn, B.; Koncz, C. T-DNA integration: In plants mode of illegitimate recombination. EMBO J. 1991, 10, 697-704. [CrossRef]

90. Salomon, S.; Puchta, H. Capture of genomic and T-DNA sequences during double-strand break repair in somatic plant cells. EMBO J. 1998, 17, 6086-6095. [CrossRef]

91. Chilton, M.-D.M.; Que, Q. Targeted integration of T-DNA into the tobacco genome at double-stranded breaks: New insights on the mechanism of T-DNA integration. Plant Physiol. 2003, 133, 956-965. [CrossRef] [PubMed]

92. Tzfira, T.; Frankman, L.R.; Vaidya, M.; Citovsky, V. Site-specific integration of Agrobacterium tumefaciens T-DNA via doublestranded intermediates. Plant Physiol. 2003, 133, 1011-1023. [CrossRef] [PubMed]

93. Zhang, Q.; Xing, H.L.; Wang, Z.P.; Zhang, H.Y.; Yang, F.; Wang, X.C.; Chen, Q.J. Potential high-frequency off-target mutagenesis induced by CRISPR/Cas9 in Arabidopsis and its prevention. Plant Mol. Biol. 2018, 96, 445-456. [CrossRef] [PubMed]

94. Song, J.; Bent, A.F. Microbial Pathogens Trigger Host DNA Double-Strand Breaks Whose Abundance Is Reduced by Plant Defense Responses. PLoS Pathog. 2014, 10, e1004226. [CrossRef] [PubMed]

95. Van Attikum, H.; Bundock, P.; Hooykaas, P.J. Non-homologous end-joining proteins are required for Agrobacterium T-DNA integration. EMBO J. 2001, 20, 6550-6558. [CrossRef]

96. Van Attikum, H.; Hooykaas, P.J.J. Genetic requirements for the targeted integration of Agrobacterium T-DNA in Saccharomyces cerevisiae. Nucleic Acids Res. 2003, 31, 826-832. [CrossRef]

97. Friesner, J.; Britt, A.B. Ku80- and DNA ligase IV-deficient plants are sensitive to ionizing radiation and defective in T-DNA integration. Plant J. 2003, 34, 427-440. [CrossRef]

98. Gallego, M.E.; Bleuyard, J.-Y.; Daoudal-Cotterell, S.; Jallut, N.; White, C.I. Ku80 plays a role in non-homologous recombination but is not required for T-DNA integration in Arabidopsis. Plant J. 2003, 35, 557-565. [CrossRef]

99. Li, J.; Vaidya, M.; White, C.; Vainstein, A.; Citovsky, V.; Tzfira, T. Involvement of KU80 in T-DNA integration in plant cells. Proc. Natl. Acad. Sci. USA 2005, 102, 19231-19236. [CrossRef]

100. Jia, Q.; Bundock, P.; Hooykaas, P.J.J.; de Pater, S. Agrobacterium tumefaciens T-DNA Integration and Gene Targeting in Arabidopsis thaliana Non-Homologous End-Joining Mutants. J. Bot. 2012, 2012, 1-13. [CrossRef]

101. Mestiri, I.; Norre, F.; Gallego, M.E.; White, C.I. Multiple host-cell recombination pathways act in Agrobacterium-mediated transformation of plant cells. Plant J. 2014, 77, 511-520. [CrossRef] [PubMed]

102. Park, S.-Y.; Vaghchhipawala, Z.; Vasudevan, B.; Lee, L.-Y.; Shen, Y.; Singer, K.; Waterworth, W.M.; Zhang, Z.J.; West, C.E.; Mysore, K.S.; et al. Agrobacterium T-DNA integration into the plant genome can occur without the activity of key non-homologous end-joining proteins. Plant J. 2015, 81, 934-946. [CrossRef] [PubMed] 
103. Kleinboelting, N.; Huep, G.; Appelhagen, I.; Viehoever, P.; Li, Y.; Weisshaar, B. The Structural Features of Thousands of T-DNA Insertion Sites Are Consistent with a Double-Strand Break Repair-Based Insertion Mechanism. Mol. Plant 2015, 8, 1651-1664. [CrossRef] [PubMed]

104. Nishizawa-Yokoi, A.; Saika, H.; Hara, N.; Lee, L.Y.; Toki, S.; Gelvin, S.B. Agrobacterium T-DNA integration in somatic cells does not require the activity of DNA polymerase $\theta$. New Phytol. 2021, 229, 2859-2872. [CrossRef] [PubMed]

105. Kralemann, L.; de Pater, S.; Shen, H.; Kloet, S.; van Schendel, R.; Hooykaas, P.J.J.; Tijsterman, M. T-DNA integration in plants requires MRE11- or TDP2-mediated removal of the 5 ' bound Agrobacterium protein VirD2. Nat. Plants 2022. submitted.

106. Knoll, A.; Fauser, F.; Puchta, H. DNA recombination in somatic plant cells: Mechanisms and evolutionary consequences. Chromosom. Res. 2014, 22, 191-201. [CrossRef]

107. Shukla, V.K.; Doyon, Y.; Miller, J.C.; Dekelver, R.C.; Moehle, E.A.; Worden, S.E.; Mitchell, J.C.; Arnold, N.L.; Gopalan, S.; Meng, X.; et al. Precise genome modification in the crop species Zea mays using zinc-finger nucleases. Nature 2009, 459, 437-441. [CrossRef]

108. Ayar, A.; Wehrkamp-Richter, S.; Laffaire, J.B.; Le Goff, S.; Levy, J.; Chaignon, S.; Salmi, H.; Lepicard, A.; Sallaud, C.; Gallego, M.E.; et al. Gene targeting in maize by somatic ectopic recombination. Plant Biotechnol. J. 2013, 11, 305-314. [CrossRef]

109. De Pater, S.; Pinas, J.E.; Hooykaas, P.J.J.; van der Zaal, B.J. ZFN-mediated gene targeting of the Arabidopsis protoporphyrinogen oxidase gene through Agrobacterium-mediated floral dip transformation. Plant Biotechnol. J. 2013, 11, 510-515. [CrossRef]

110. Watanabe, K.; Breier, U.; Hensel, G.; Kumlehn, J.; Schubert, I.; Reiss, B. Stable gene replacement in barley by targeted double-strand break induction. J. Exp. Bot. 2016, 67, 1433-1445. [CrossRef]

111. De Pater, S.; Klemann, B.J.P.M.; Hooykaas, P.J.J. True gene-targeting events by CRISPR/Cas-induced DSB repair of the PPO locus with an ectopically integrated repair template. Sci. Rep. 2018, 8, 2-11. [CrossRef] [PubMed]

112. Reiss, B.; Schubert, I.; Köpchen, K.; Wendeler, E.; Schell, J.; Puchta, H. RecA stimulates sister chromatid exchange and the fidelity of double-strand break repair, but not gene targeting, in plants transformed by Agrobacterium. Proc. Natl. Acad. Sci. USA 2000, 97, 3358-3363. [CrossRef] [PubMed]

113. Shaked, H.; Melamed-Bessudo, C.; Levy, A.A. High-frequency gene targeting in Arabidopsis plants expressing the yeast RAD54 gene. Proc. Natl. Acad. Sci. USA 2005, 102, 12265-12269. [CrossRef] [PubMed]

114. Kooistra, R.; Hooykaas, P.J.J.; Steensma, H.Y. Efficient gene targeting in Kluyveromyces lactis. Yeast 2004, 21, 781-792. [CrossRef]

115. De Boer, P.; Bastiaans, J.; Touw, H.; Kerkman, R.; Bronkhof, J.; van den Berg, M.; Offringa, R. Highly efficient gene targeting in Penicillium chrysogenum using the bi-partite approach in $\Delta$ lig4 or $\Delta$ ku70 mutants. Fungal Genet. Biol. 2010, 47, 839-846. [CrossRef]

116. Qi, Y.; Zhang, Y.; Zhang, F.; Baller, J.A.; Cleland, S.C.; Ryu, Y.; Starker, C.G.; Voytas, D.F. Increasing frequencies of site-specific mutagenesis and gene targeting in Arabidopsis by manipulating DNA repair pathways. Genome Res. 2013, 23, 547-554. [CrossRef]

117. Endo, M.; Mikami, M.; Toki, S. Biallelic gene targeting in rice. Plant Physiol. 2016, 170, 667-677. [CrossRef]

118. Even-Faitelson, L.; Samach, A.; Melamed-Bessudo, C.; Avivi-Ragolsky, N.; Levy, A.A. Localized egg-cell expression of effector proteins for targeted modification of the Arabidopsis genome. Plant J. 2011, 68, 929-937. [CrossRef]

119. Saito, S.; Maeda, R.; Adachi, N. Dual loss of human POLQ and LIG4 abolishes random integration. Nat. Commun. 2017, 8, 16112. [CrossRef]

120. Van Tol, N.; van Schendel, R.; Bos, A.; van Kregten, M.; de Pater, S.; Hooykaas, P.J.J.; Tijsterman, M. Gene targeting in polymerase theta-deficient Arabidopsis thaliana. Plant J. 2022, 109, 112-125. [CrossRef]

121. Urnov, F.D.; Rebar, E.J.; Holmes, M.C.; Zhang, H.S.; Gregory, P.D. Genome editing with engineered zinc finger nucleases. Nat. Rev. Genet. 2010, 11, 636-646. [CrossRef] [PubMed]

122. Durai, S.; Mani, M.; Kandavelou, K.; Wu, J.; Porteus, M.H.; Chandrasegaran, S. Zinc finger nucleases: Custom-designed molecular scissors for genome engineering of plant and mammalian cells. Nucleic Acids Res. 2005, 33, 5978-5990. [CrossRef] [PubMed]

123. De Pater, S.; Neuteboom, L.W.; Pinas, J.E.; Hooykaas, P.J.J.; Van Der Zaal, B.J. ZFN-induced mutagenesis and gene-targeting in Arabidopsis through Agrobacterium-mediated floral dip transformation. Plant Biotechnol. J. 2009, 7, 821-835. [CrossRef]

124. Wang, M.; Lu, Y.; Botella, J.R.; Mao, Y.; Hua, K.; Zhu, J. kang Gene Targeting by Homology-Directed Repair in Rice Using a Geminivirus-Based CRISPR/Cas9 System. Mol. Plant 2017, 10, 1007-1010. [CrossRef] [PubMed]

125. Fauser, F.; Roth, N.; Pacher, M.; Ilg, G.; Sanchez-Fernandez, R.; Biesgen, C.; Puchta, H. In planta gene targeting. Proc. Natl. Acad. Sci. USA 2012, 109, 7535-7540. [CrossRef] [PubMed]

126. Wolter, F.; Klemm, J.; Puchta, H. Efficient in planta gene targeting in Arabidopsis using egg cell-specific expression of the Cas9 nuclease of Staphylococcus aureus. Plant J. 2018, 94, 735-746. [CrossRef] [PubMed]

127. Gil-Humanes, J.; Wang, Y.; Liang, Z.; Shan, Q.; Ozuna, C.V.; Sánchez-León, S.; Baltes, N.J.; Starker, C.; Barro, F.; Gao, C.; et al. High-efficiency gene targeting in hexaploid wheat using DNA replicons and CRISPR/Cas9. Plant J. 2017, 89, 1251-1262. [CrossRef]

128. Dahan-Meir, T.; Filler-Hayut, S.; Melamed-Bessudo, C.; Bocobza, S.; Czosnek, H.; Aharoni, A.; Levy, A.A. Efficient in planta gene targeting in tomato using geminiviral replicons and the CRISPR/Cas9 system. Plant J. 2018, 95, 5-16. [CrossRef]

129. Miki, D.; Zhang, W.; Zeng, W.; Feng, Z.; Zhu, J.K. CRISPR/Cas9-mediated gene targeting in Arabidopsis using sequential transformation. Nat. Commun. 2018, 9, 1-9. [CrossRef]

130. Begemann, M.B.; Gray, B.N.; January, E.; Gordon, G.C.; He, Y.; Liu, H.; Wu, X.; Brutnell, T.P.; Mockler, T.C.; Oufattole, M. Precise insertion and guided editing of higher plant genomes using Cpf1 CRISPR nucleases. Sci. Rep. 2017, 7, 1-6. [CrossRef] 
131. Ma, M.; Zhuang, F.; Hu, X.; Wang, B.; Wen, X.Z.; Ji, J.F.; Xi, J.J. Efficient generation of mice carrying homozygous double-floxp alleles using the Cas9-Avidin/Biotin-donor DNA system. Cell Res. 2017, 27, 578-581. [CrossRef] [PubMed]

132. Aird, E.J.; Lovendahl, K.N.; St Martin, A.; Harris, R.S.; Gordon, W.R. Increasing Cas9-mediated homology-directed repair efficiency through covalent tethering of DNA repair template. Commun. Biol. 2018, 1, 54. [CrossRef] [PubMed]

133. Savic, N.; Ringnalda, F.C.A.S.; Lindsay, H.; Berk, C.; Bargsten, K.; Li, Y.; Neri, D.; Robinson, M.D.; Ciaudo, C.; Hall, J.; et al. Covalent linkage of the DNA repair template to the CRISPR-Cas9 nuclease enhances homology-directed repair. eLife 2018, 7, 1-18. [CrossRef]

134. Charpentier, M.; Khedher, A.H.Y.; Menoret, S.; Brion, A.; Lamribet, K.; Dardillac, E.; Boix, C.; Perrouault, L.; Tesson, L.; Geny, S.; et al. CtIP fusion to Cas9 enhances transgene integration by homology-dependent repair. Nat. Commun. 2018, 9, 1-11. [CrossRef] [PubMed]

135. Smih, F.; Rouet, P.; Romanienko, P.J.; Jasin, M. Double-strand breaks at the target locus stimulate gene targeting in embryonic stem cells. Nucleic Acids Res. 1995, 23, 5012-5019. [CrossRef] [PubMed]

136. Joung, J.K.; Sander, J.D. TALENs: A widely applicable technology for targeted genome editing. Nat. Rev. Mol. Cell Biol. 2013, 14, 49-55. [CrossRef]

137. Christian, M.; Cermak, T.; Doyle, E.L.; Schmidt, C.; Zhang, F.; Hummel, A.; Bogdanove, A.J.; Voytas, D.F. Targeting DNA double-strand breaks with TAL effector nucleases. Genetics 2010, 186, 756-761. [CrossRef]

138. Zhang, F.; Cong, L.; Lodato, S.; Kosuri, S.; Church, G.M.; Arlotta, P. Efficient construction of sequence-specific TAL effectors for modulating mammalian transcription. Nat. Biotechnol. 2011, 29, 149-153. [CrossRef]

139. Cermak, T.; Doyle, E.; Christian, M. Efficient design and assembly of custom TALEN and other TAL effector-based constructs for DNA targeting. Nucleic Acids Res. 2011, 39, e82. [CrossRef]

140. Jinek, M.; Chylinski, K.; Fonfara, I.; Hauer, M.; Doudna, J.A.; Charpentier, E. A programmable dual-RNA-guided DNA endonuclease in adaptive bacterial immunity. Science 2012, 337, 816-821. [CrossRef]

141. Zetsche, B.; Gootenberg, J.S.; Abudayyeh, O.O.; Slaymaker, I.M.; Makarova, K.S.; Essletzbichler, P.; Volz, S.E.; Joung, J.; Van Der Oost, J.; Regev, A.; et al. Cpf1 Is a Single RNA-Guided Endonuclease of a Class 2 CRISPR-Cas System. Cell 2015, 163, 759-771. [CrossRef] [PubMed]

142. Paul, B.; Montoya, G. CRISPR-Cas12a: Functional overview and applications. Biomed. J. 2020, 43, 8-17. [CrossRef] [PubMed] 